\title{
El Salvador
}

National Cancer Institute

\section{Source}

National Cancer Institute. El Salvador. NCI Thesaurus. Code C16532.

A country in Central America, bordering the North Pacific Ocean, between Guatemala and Honduras. 